\title{
PRIMARY STAGE OF PAKIS-STEM-BLOCK SYSTEM AS THERMAL PROTECTIVE TO FLAT BARE CONCRETE ROOFTOP IN TROPICAL CLIMATE OF SURABAYA
}

\author{
Danny Santoso Mintorogo ${ }^{1}$, Mohd. Hamdan Ahmad ${ }^{2}$ \\ ${ }^{1)}$ Department of Architecture, Tropical Housing Studies, Petra Christian University, \\ Surabaya, Indonesia 60235. \\ Email: dannysm@peter.petra.ac.id \\ ${ }^{2)}$ Institute Sultan Iskandar, Universiti Teknologi Malaysia, Johor Bahru, Malaysia. \\ Email: b-hamdan@utm.my
}

\begin{abstract}
In the era of global warming and increasing urban heat island condition, flat concrete deck on shop-houses may be less sustainable to handle the excessive solar heat radiation impacts on the roof surfaces. Innovative alternative roofing system is needed to manage heat radiation that will lead to sustainable factors likes energy savings, less energy body used on the roofing materials, and provide comprehensive environmental friendly roof system. This paper discusses about particular environmental friendly materials such as "Pakis-Stem Blocks" system is a good thermal resistant to absorb the solar sun heat and provide natural cooling through convective-wind without adding substantial loads to the roof structures. "Pakis-stem blocks" are easier, cheaper and more valuable than other sub-structure roofing materials as thermal resistant layer on flat bare concrete deck besides green roofing systems.
\end{abstract}

Keywords: Flat bare concrete roof, pakis-stem blocks, thermal protective.

\section{INTRODUCTION}

From $20^{\text {th }}$ to $21^{\text {th }}$ centuries in Indonesia, commercial buildings, some residential housings, multifamily dwellings, shop-offices, and shop-houses have been commonly built with rooftop concrete flat roofing for easy of expanding spaces in the future. The concrete flat decking rooftop systems are simple; the reinforced concrete rooftop structures are around 120 $\mathrm{mm}$ to $200 \mathrm{~mm}$. The rooftop flat concrete decks are mostly built without outer and inner layers of insulation and no special thermal sheet barrier covers likes asphalt roll, thermoplastic polymer, single-ply membrane, and cool roofing coatings. The surface thermal performance of concrete rooftop flat deck in hot and humid tropical climate of dry season in late July during the daytime ( 6 am to $6 \mathrm{pm}$ ) has an average of $38.6^{\circ} \mathrm{C}$ and concrete surface deck temperature during the nighttime $(6 \mathrm{pm}$ to $6 \mathrm{am})$ is average of $31.8^{\circ} \mathrm{C}$. The peak concrete surface decking temperature is $54.8^{\circ} \mathrm{C}$ at $12.20 \mathrm{pm}$.

Figure 1 and Figure 2 show the flat rooftop concrete decks on shop-houses at two commercial zones, most shop-houses have been entirely operated with air conditioning systems, and those two-story shop-houses are fully functioned as commercial spaces likes restaurants, offices, and stores. Figures 1 (commercial zones at Manyar Kertoarjo street) has around 10,100 square meters of rooftop concrete decks; other com- mercial shop-houses at Galaxy street have nearby 12,400 square meters (Figure 2).

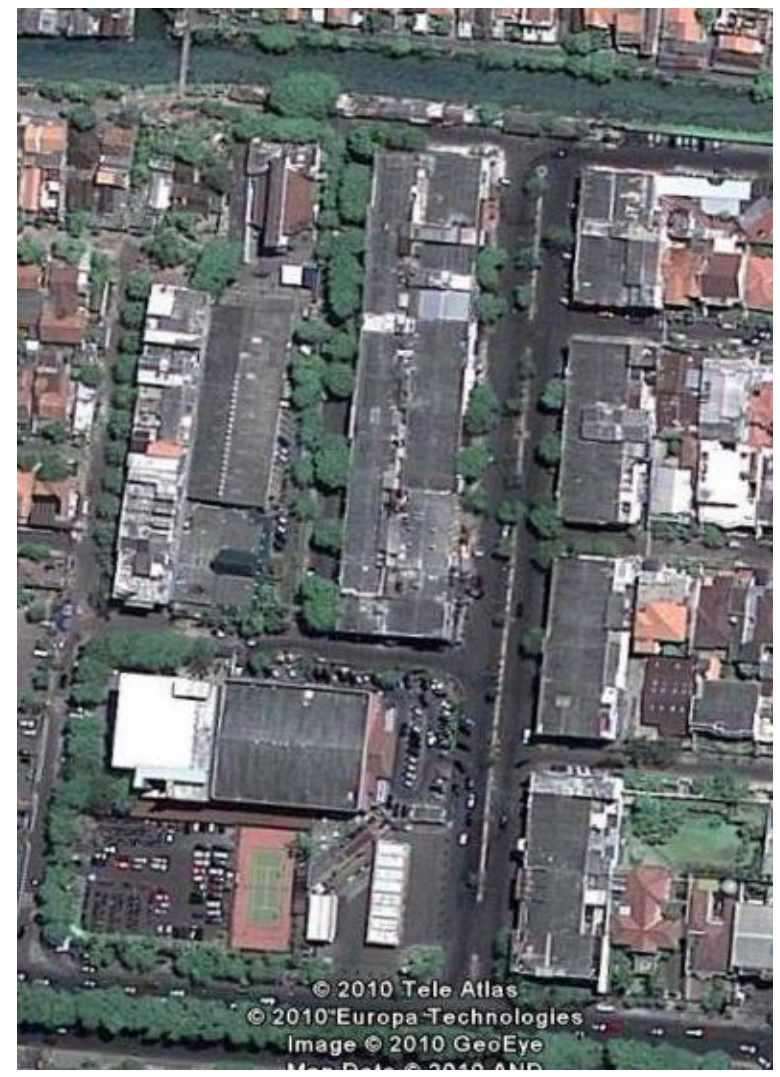

Figure 1. Rooftop Concrete deck of 10,100 $\mathrm{m}^{2}$ 


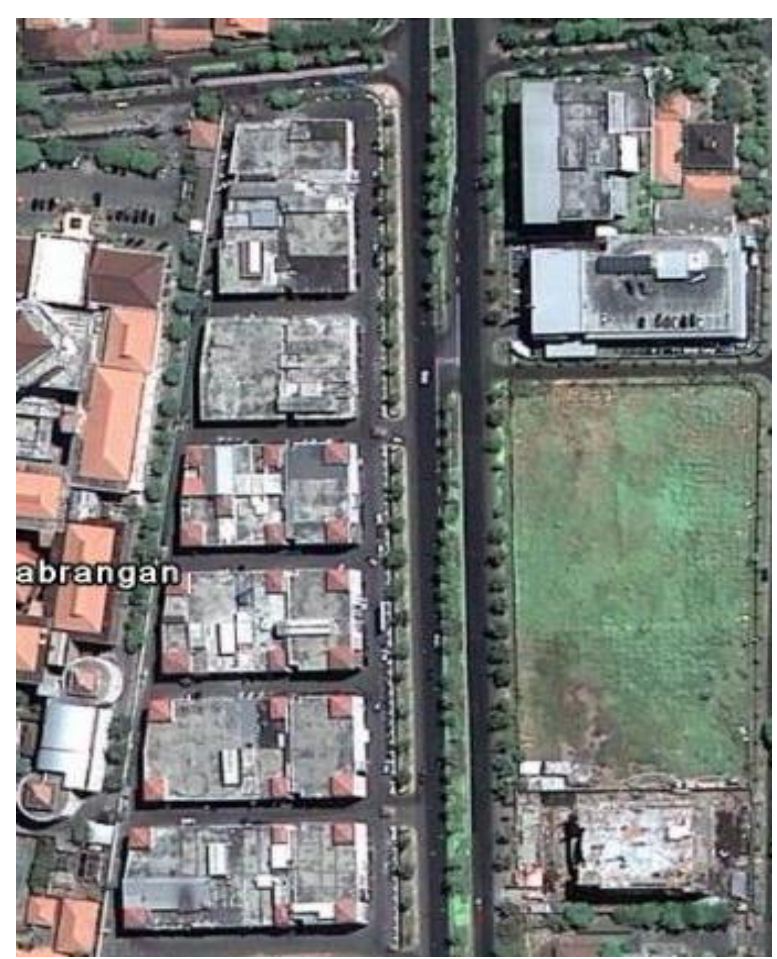

Figure2. Rooftop Concrete of 12,400 $\mathrm{m}^{2}$ (Author, 2010)

The total average of 12 hours of heat solar irradiation on horizontal surface per day during July month has an average of 400 Wh.m ${ }^{-2}$. Meanwhile, maximum hourly horizontal solar irradiance can reach to 900 to $1,000 \mathrm{~W} \cdot \mathrm{m}^{-2}$ (Mintorogo, 2008).

The concrete rooftop flat decks are mostly dominated built than metal or steel rooftop decks. Table 1 shows that reinforced concrete structures have lower production energy materials than metal (Alsamsam et al. 2009). This could help leading to sustainable concrete structure.

\section{Global Warming Aspects}

Global warming is the process of rising of the average atmospheric temperature, earth-temperature, sea-level, and greenhouse gases such as carbon dioxide, water, and hydrocarbon. The concentration of the atmospheric of $\mathrm{CO}_{2}$ will has risen the earth temperature and causing the global warming of the air temperature. Some political science leaders said that the global warming can be a myth, because the evident of rising of the carbon dioxide and temperature in the atmosphere has been happening from the past 3000 till 50 years (Robison et al. 1997). Robinson also stated that carbon dioxide and hydrocarbon in the atmosphere actually did not harm all creatures in the earth, yet those $\mathrm{CO}_{2}$ and $\mathrm{HC}$ play a major role for accelerating the growth rates of plants and the growth endeavour in drier region environ- mental. According to COP-15 conference results that are struggling to set out the post-Kyoto Protocol framework (limiting world greenhouse gases emission to slow the progress of global warming), China is already the world largest $\mathrm{CO}_{2}$ emitter than the United States in 2007 and will overtake the entire European continent around 2013 (Kanekiyo, K. 2010). Figure 3, Kanekiyo shows the world $\mathrm{CO}_{2}$ emissions taken from IEEJ (The Institute of Energy Economic, Japan); China will become the leader of not only producing coals but producing also $\mathrm{CO}_{2}$ till year 2035. Indonesia now is the third largest in the world for producing the $\mathrm{CO}_{2}$ emission due to the deforestation (Murray, I. 2008, http://www.mongabay.com 2007).

The world atmospheric temperature has already soared to around $0.6^{\circ} \mathrm{C}$ with linking to global warming; meanwhile mean annual temperature has increased by about $0.3^{\circ} \mathrm{C}$ in Indonesia (Hulme, M. et al. 1999, Boer et al. 2004). In addition to the risen of world atmospheric temperature, the earth temperature has also escalated to $0.74 \%$ or $+-0.18^{\circ} \mathrm{C}$ for 100 year decade http://id.wikipedia.org/wiki/Pemanasan_global).

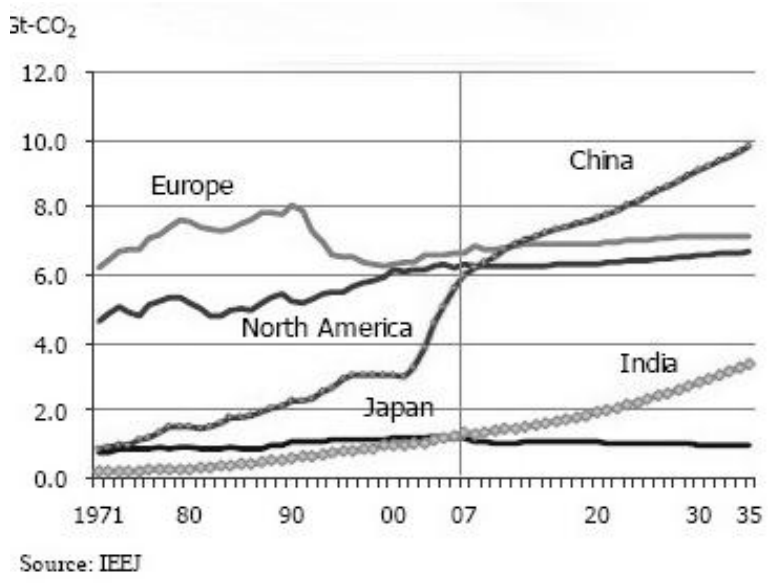

Figure 3. The World Carbon Dioxide Emissions (Kanekiyo, 2010)

\section{Sustainable Aspects}

Approaching sustainable building means moving toward with as much as renewable energy resources in building used, and minimizing a building's environmental impacts throughout its life cycle. Sustainable buildings can be achieved by integrated building design and structure; choosing the right structural systems likes steel, wood, or concrete will lead to save amount of embodied energy needed for sustainable architecture in the future. Planning a flat rooftop concrete deck instead of metal or steel rooftop flat deck will create a sustainable high performance of concrete building. According to Marceau et al. (2007b), concretes generally have light color, so 
it will reflect the solar spectrum and heat of the sun back to the atmosphere. A typical solar reflectance of at least 0.3 on concrete will correspond to a solar reflectance index (SRI) of 29. Thus creating a very reflective concrete (by painting white or putting white cement on concrete) will obtain a SRI of 78. Concrete has less $\mathrm{CO}_{2}$ in terms of producing Portland cement; it embodied around 100 to $300 \mathrm{Kg}$ of $\mathrm{CO}_{2}$ in an every cubic meter of concrete, besides concrete will reabsorb the $\mathrm{CO}_{2}$ in the air through a process called carbonation during the product life cycle. $1 \mathrm{~m}^{3}$ of concrete weighs approximately $2400 \mathrm{Kg}$. A research showed on table 1 that reinforced concrete as building structure and rooftop flat deck will only need $2.5 \mathrm{GJ} / \mathrm{t}$ of energy production of extracting, transporting, and manufacturing raw materials into building materials than building material for steel structure of $30 \mathrm{GJ} / \mathrm{t}$. Table 1 shows the embodied energy production for concrete and other common building materials; reinforced concrete rooftop flat deck is going to be a sustainable building materials in terms of its low embodied energy used for rooftop.

Table 1. Embodied Energy for Various Building Materials

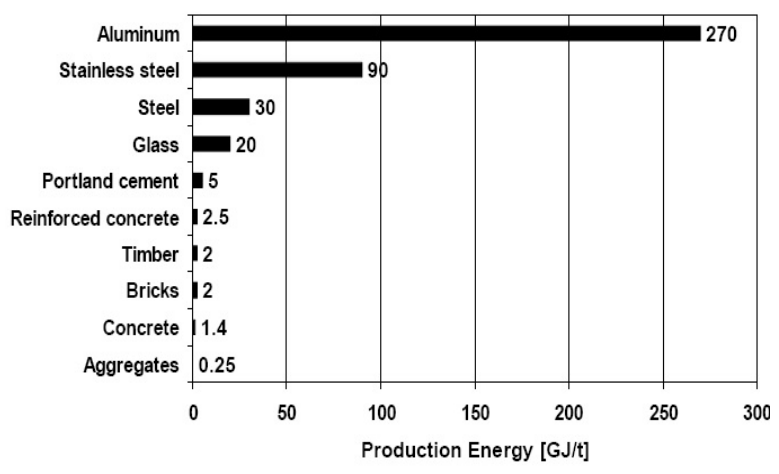

\section{Problem Statement}

Because most of the concrete rooftop flat deck at commercial buildings, and shop-houses are built with bare flat reinforced concrete materials, the cooling loads due to intent high heat solar radiation on horizontal surface will burden the use of air conditioning that leads to a un-energy saving domain.

\section{GOALS OF RESEARCH}

In reponding to sustainable architectural design schemes, world's global warming aspects, and users friendly environment materials for energy savings in cooling loads due to common use of bare concrete flat deck rooftop on shop-houses and commercial roofs, this research seeks the right friendly environmental materials-Pakis/Picas-stem-blocks as outer heat barrier to covering over the existed rooftop concrete flat deck -that minimize the cooling loads in tropical hot and humid climate of Surabaya.

\section{LITERATURE REVIEWS}

Types of flat roof systems are commonly used throghout the United States and other countries. The common base structural roof is flat concrete deck and will be covered with varities of roof membrane materials. Several factors to be concerned are their durability and cost; the flat roofs are roll asphalt, aingle-ply membrane, multiple-ply, and flat-seamed metal and vegetated roofs.

\section{Asphalt Roll Roofing}

Used since year 1890 till now, asphalt sheet roll which consist of one layer of asphalt-saturated organic or fiberglass base felts. Asphalt roll membrane is applied by nails and cold asphalt cement, and sometime covered with granular mineral over top of asphalt membrane; the membrane could last around 10 years.

\section{Single-ply Membrane Roofing}

These single-ply roofing membranes commonly used are thermoset, thermoplastic, or modified bitumen. Those membranes are less expensive to install, durable, lighter in weight, and produced in two colors-white and black. Single-ply membrane lasts 10 to 20 years, and the newest single-ply membranes are made with self-cleaning and mold-resistant polymers to maintain solar reflectance. The leader famous single-ply membranes used is EPDM (ethylene propylene diene terpolymer; EPDM is a rubber roofing membrane, and it has last about 25 years in the market. TPO (thermoplastic polyolefin) white or black membrane is a blend of polymers which could contain or not the desirable additives of UV absorbers. TPO could last around 30 years and is largely maintenance free product. Other products roofing membrane are PVC-a synthetic thermoplastic polymer; it is the most expensive of the three products but it has excellent durability on long-term performance.

\section{PAKIS-STEM-BLOCKS}

"Pakis" or Picas trees grow healthly in the tropical forest; the Picas trees could grow till around 2.5 to 4 meter height, and have plenty of leaves. Its stem 
has diameter roughly 200 to $400 \mathrm{~mm}$, and very porosity. The stems then are sliced to pieces of stemblocks with dimension of $260 \mathrm{~mm}$ length, $130 \mathrm{~mm}$ width, and $30 \mathrm{~mm}$ thick. Figure 4 (a to c) gives a closer look to the Picas trees and sliced block. Those pakis stems or blocks are widely use as interior decoration materials and sliced pakis stem blocks have been consumed by orchid users and are sold in flower stores.

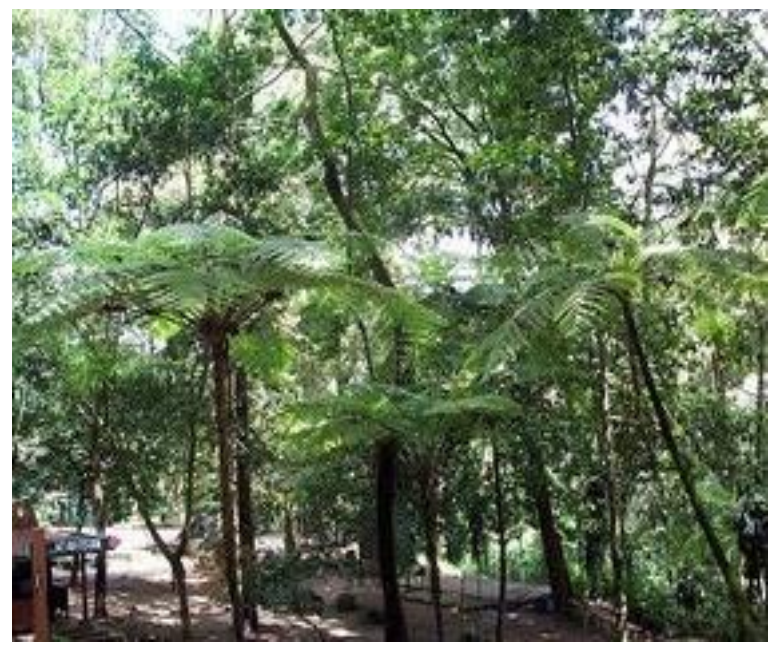

(a)

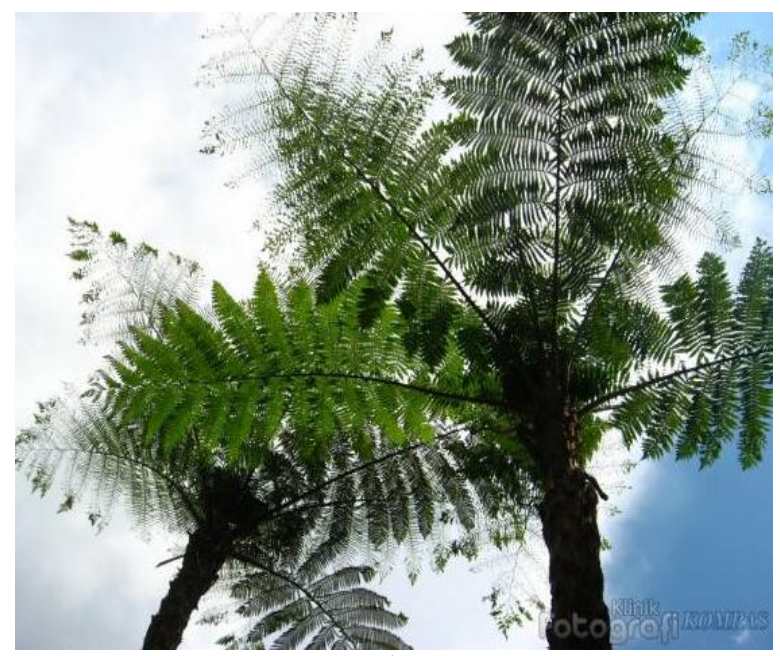

(b)

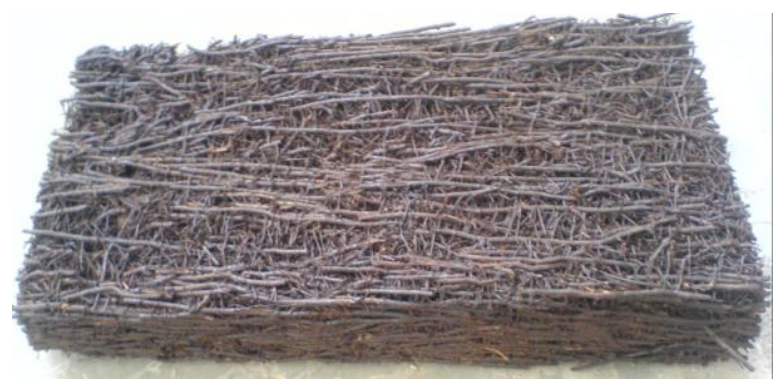

(c)

Figure 4. Pakis "Picas" trees in the forest (a) and (b), sliced Pakisstem-block (c), (author, 2010)

\section{METHODOLOGY}

Research on gathering the sustainable rooftop flat concrete thermal performance for savings energy on cooling loads is dealing with two model; one is for reference model, and the other model is covering with organic Picas-stem-block. Each model is measured its thermal performance for 6 days continuously and simultaneously. There will be two-system measurements; one measurement is dry Pakis-stem-block, and others is wet Pakis-stem-block. With wet mode, the Pakis-stem-blocks are sprayed two times per day; that is at 6 am and 12 noon. All test models are in closed mode system-no ventilation opening; just having infiltration through door and walls.

\section{Models Testing}

The models have dimension of 1000 wide $\mathrm{x}$ 1000 length $\mathrm{x} 1000 \mathrm{~mm}$ height. The floor is lifted 500 $\mathrm{mm}$ distance from ground. The rooftop flat concrete flat deck of $800 \mathrm{~mm}$ thick is 1000 wide $\mathrm{x} 1000$ length x $400 \mathrm{~mm}$ height. The walls are of portland cement (kalsi) boards of $40 \mathrm{~mm}$ thick. The walls and floor are covered with $200 \mathrm{~mm}$ foam boards as interior surfaces. No horizontal shading device and styrofoam stick on the exterior 4-side walls (natural mode). Figure 5 descrebes the model reference (a) and one layer Picas-stem covered model (b); one layer of Picas-stem-block of 1 square meter has 27 blocks. The total weight of dry Picas-stem-block of $1 \mathrm{~m}^{2}$ is 6 kilo-gram, meanwhile the wet Picas-stem-block on 1 $\mathrm{m}^{2}$ weigh up $9 \mathrm{~kg}$.

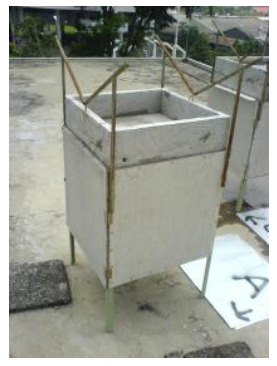

(a)

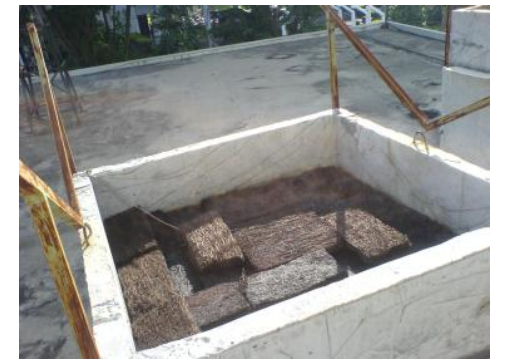

(b)

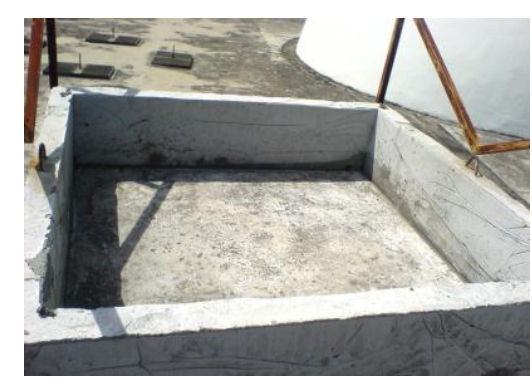

(c)

Figure 5. The Researched Models (a) and Pakis (Picas)-StemBlocks covered on Mode (b)), Reference Model with flat concrete rooftop (c), (author, 2010) 


\section{Equipment}

The measuring equipment is one piece of HOBO U15 with four external data logger water/soil temperature sensors. 1 sensor is connected to Pakisstem-block; and other one sensor is clinged to concrete surface. Another 1 sensor is sticked to the internal concrete model; and the rest is for the interior temperature. Figure 6 shows the HOBO U family has a mesurement range of temperature from $-20^{\circ} \mathrm{C}$ to $70^{\circ} \mathrm{C}$; $\mathrm{Rh}$ is $5 \%$ to $95 \%$. The external input channels have a 0 to $2.5 \mathrm{DC}$ volts; and the mesurement range is $-40^{\circ} \mathrm{C}$ to $50^{\circ} \mathrm{C}$ in water, while it ranges $-40^{\circ} \mathrm{C}$ to $100^{\circ} \mathrm{C}$ in air.

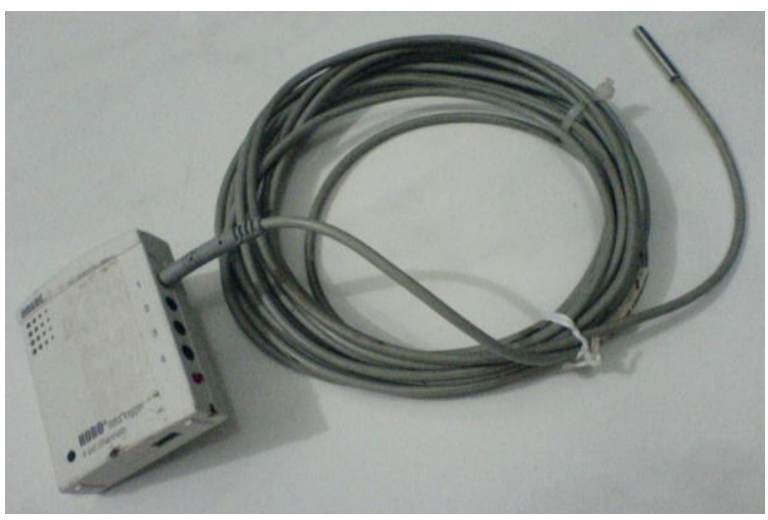

Figure 6. HOBO U Family Data Logger and External Water or Soil Sensor, (author, 2010)

\section{RESULTS}

The concrete surface temperature at reference model has an average of $35.9^{\circ} \mathrm{C}$; meanwhile the maximum surface temperature can reache to $52^{\circ} \mathrm{C}$ at noon, and the lowest temperature is $27.9^{\circ} \mathrm{C}$ at $6 \mathrm{am}$. The inner concrete ceiling surface temperature reaches an average of $34.2^{\circ} \mathrm{C}$, and the highest temperature is $47.9^{\circ} \mathrm{C}$ at $2 \mathrm{pm}$. The lowest inner ceiling concrete reference model temperature is $28^{\circ} \mathrm{C}$ at 6 am (figure 7).

Figure 8 describes the thermal performance flat concrete rooftop model with completely dry Pakisstem-blocks covered over the flat concrete deck. The average of dry Pakis-stem-block temperature is $32.7^{\circ} \mathrm{C}$. The maximum dry Pakis-stem-block temperature at noon is $34.4^{\circ} \mathrm{C}$, outdoor of $31.6^{\circ} \mathrm{C}$, concrete surface temperature of $36.7^{\circ} \mathrm{C}$ at $4 \mathrm{pm}$, inner ceiling concrete temperature of $38.3^{\circ} \mathrm{C}$ at $2 \mathrm{pm}$, and the room temperature of $39.7^{\circ} \mathrm{C}$ at $4 \mathrm{pm}$. The lowest dry Pakis temperature at $6 \mathrm{am}$ is $28.2^{\circ} \mathrm{C}$, outdoor temperature of $28.7^{\circ} \mathrm{C}$, dry concrete surface temperature of $29.2^{\circ} \mathrm{C}$, inner concrete ceiling temperature of $29.0^{\circ} \mathrm{C}$, and the room temperature of $26.5^{\circ} \mathrm{C}$.

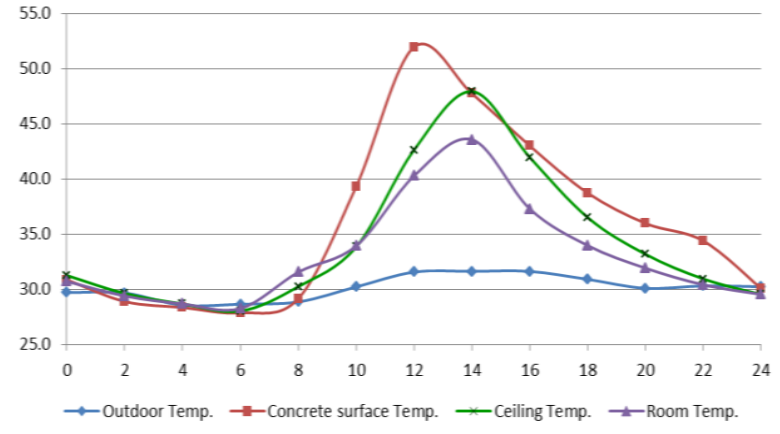

Figure 7. Reference Model Thermal Performance

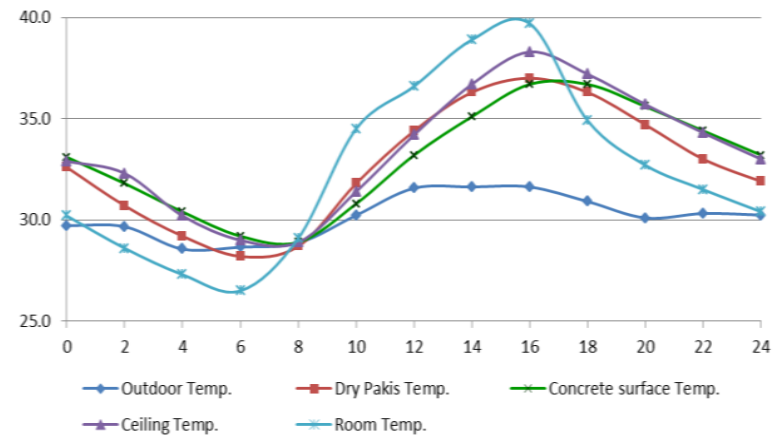

Figure 8. Dry Pakis-Stem-Blocks Model Thermal Performance

In the meantime, figure 9 shows the wet Pakisstem-blocks thermal performance. All lowest thermal temperatures are happended as usualy at $6 \mathrm{am}$; the outdoor shaded temperature, wet pakis-stem-block, rooftop flat concrete surface, inner concrete ceiling, and room temperatures respectively as $28.7^{\circ} \mathrm{C}$, $24.9^{\circ} \mathrm{C}, 25.6^{\circ} \mathrm{C}, 26.3^{\circ} \mathrm{C}$, and $26.0^{\circ} \mathrm{C}$. With wet Pakisstem-blocks covered, the rooftop concrete surface temperature is lower $3.6^{\circ} \mathrm{C}$ than covered with dry pakis-stem-blocks. The rooftop surface concrete temperature difference at peak $(4 \mathrm{pm})$ is $6.80 \mathrm{C}$ with wet pakis-stem-cloks covered than with dry ones. The maximum wet Pakis-stem-bloks temperature happended at $2 \mathrm{pm}$ is $29.0^{\circ} \mathrm{C}$; the outter flat rooftop concrete surface temperature happended at $2 \mathrm{pm}$ of $30.1^{\circ} \mathrm{C}$, room temperature of $31.1^{\circ} \mathrm{C}$. The concrete ceilling temperature is highest at $4 \mathrm{pm}$ of $31.5^{\circ} \mathrm{C}$. The average temperature of wet pakis-stem, outter surface concrete rooftop, inner concrete ceiling, and room model respectively as follows: $27.1^{\circ} \mathrm{C}, 27.9^{\circ} \mathrm{C}, 28.5^{\circ} \mathrm{C}$, and $29.0^{\circ} \mathrm{C}$.

For the moment of comparation between the thermal performance of otter flat concrete rooftop on reference model, dry and wet Pakis-sterm-blocks covered, figure 10 shows great difference on wet Pakis-stem-blocks thermal performance which has lower thermal performace than bare-concrete flat rooftop. The average reference flat concrete rooftop temperature is $35.9^{\circ} \mathrm{C}$, and the dry and wet pakis- 
stem-block covered flat concrete surface temperatures are respectively of $33.0^{\circ} \mathrm{C}$ and $27.9^{\circ} \mathrm{C}$. So the average temperatures difference are $2.9^{\circ} \mathrm{C}$ for dry Pakis-stemblock covered; and $8.0^{\circ} \mathrm{C}$ for the wet Pakis-stemblocks concrete surface covered. The maximum temperatures at noon of flat bare concrete rooftop, drystem-blocks covered, wet Pakis-stem Blocks concrete rooftop covered are $52.0^{\circ} \mathrm{C}, 33.2^{\circ} \mathrm{C}$ and $28.9^{\circ} \mathrm{C}$ respectively.

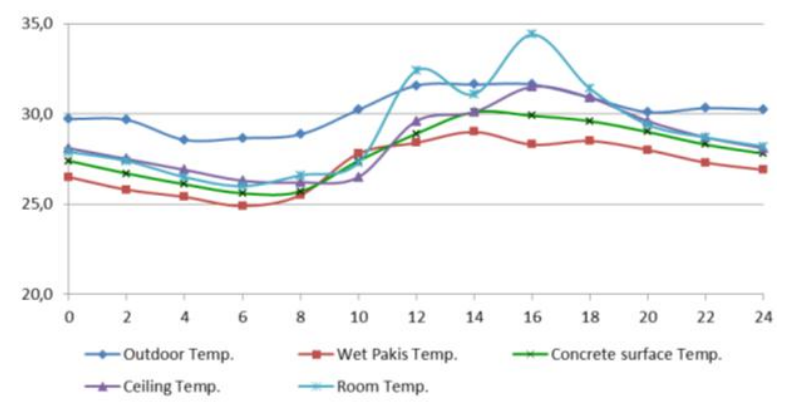

Figure 9. Wet Pakis-Stem-Blocks Thermal Performance.

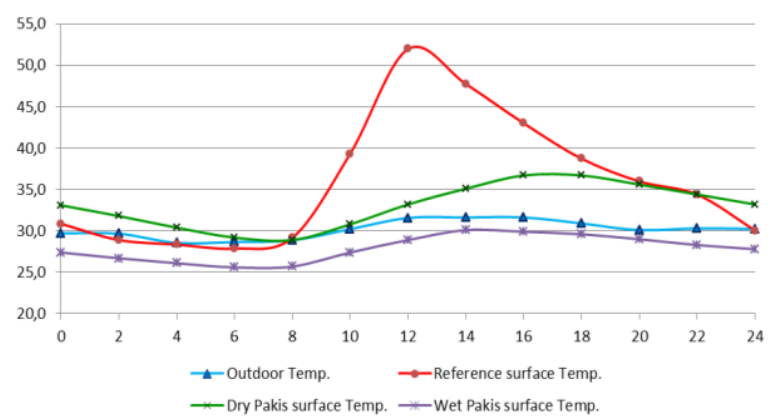

Figure 10. Surface Concrete Temperature Differences of Reference model, Dry and Wet Pakis-Stem-Blocks Covered

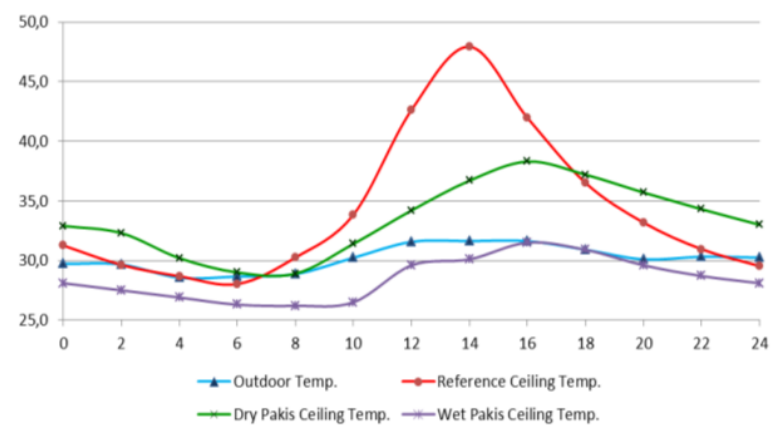

Figure 11. The Ceiling Concrete Temperatures of Reference model, Dry and Wet Pakis-Stem-Blocks

Let's see the figure 11, the average inner concrete ceiling temperatures of the reference, dry and wet Pakis-stem-blocks model are $34.2^{\circ} \mathrm{C}, 33.4^{\circ} \mathrm{C}$, and $28.5^{\circ} \mathrm{C}$ respectively. The highest ceiling temperatures of the three models occored at $4 \mathrm{pm}$. The reference model has the maximum temperature of $47.9^{\circ} \mathrm{C}$ at 2 pm, while the dry Pakis-stem-blocks concrete ceiling temperature is $36.7^{\circ} \mathrm{C}$ at $2 \mathrm{pm}$, and the wet Pakisstem-blocks concrete ceiling temperature is $30.1^{\circ} \mathrm{C}$ at $4 \mathrm{pm}$. The thermal heat conduction from solar heat radiation impacted on flat concrete rooftop could be reduced significantly about $11.2^{\circ} \mathrm{C}$ if it covers with dry Pakis-stem blocks and about $17.8^{\circ} \mathrm{C}$ with wet Pakis-stem blocks.

Observed the figure 12, the room temperature of the reference model is higher than dry and wet-stemblocks systems. The room temperature of those modified organic roofing systems are higher from 6 am to $10 \mathrm{pm}$ than outdoor temperature, this phenomenon are due to closed mode passive systeminfiltration only. Figure 12 demonstrates those organic material on rooftop of flat concrete could reduce the heat of solar irradiation that impacted during daytime (from 11 am to midnight). The average of room temperature covered with dry-stem-blocks is $31.6^{\circ} \mathrm{C}$. Covered with wet-stem-blocks save only $0.6^{\circ}$ compare to dry system. Meanwhile the average reference room temperature is $33^{\circ} \mathrm{C}$, and the shaded outdoor temperature is $30.2^{\circ} \mathrm{C}$ on July month. The maximum room temperature at noon at reference model is $40.3^{\circ} \mathrm{C}$, and the model covered with dry-stem-blocks is $36.6^{\circ} \mathrm{C}$. The wet-stem-blocks model is $32.4^{\circ} \mathrm{C}$. Meanwhile the outdoor temperature at $6 \mathrm{am}$ is $28.7^{\circ} \mathrm{C}$, the lowest room temperature for reference, dry, and wet-stem-blocks model are of $28.3^{\circ} \mathrm{C}, 26.5^{\circ} \mathrm{C}, 26^{\circ} \mathrm{C}$ respectively.

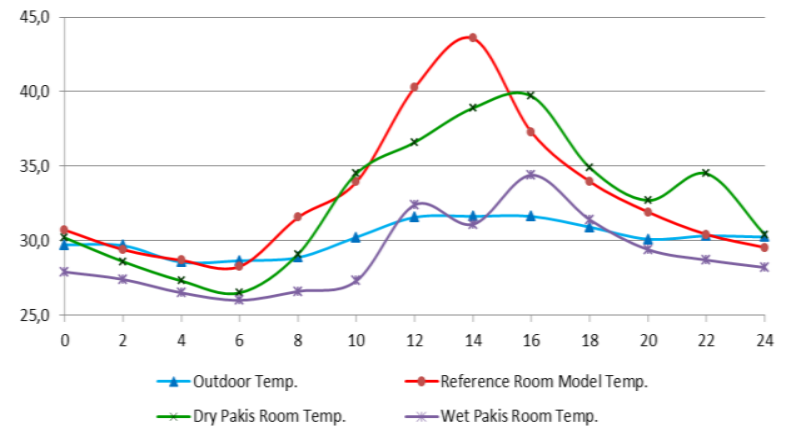

Figure 12. The Room Temperature of Reference model, Dry and Wet Pakis-Stem-Blocks

\section{CONCLUSION}

Based on the thermal performance at figure 6 to 11 of concrete surface rooftop temperature, inner concrete ceiling and high room temperature, the modified flat concrete rooftop covered with dry or wet Pakis-stem-blocks system definitely could reduced the need of cooling loads of air conditioning. All models have high room temperatures due to getting impacted heat irradiation through the 4-sided walls instead of merely rooftop concrete. For future investigating on pakis-stem blocks preventing heat 
flux through rooftop concrete only, horizontal shading devices and wall insulations have to be installed on models.

\section{Acknowledgement}

I gratefully thank to Prof. Mohd. Hamdan for his great support to make this paper done. Also thanks to the department of architecture, tropical housing studies laboratory for providing equipment for measurements.

\section{REFERENCE}

Alsamsam, I., Lionel L., Martha G.V.G. (2009). Sustainable High Performance Concrete Buildings, Illinois

Boer, R., A. Faqih, (2004). Current and Future Rainfall Variability in Indonesia. In An Integrated Assessment of Climate Change Impacts, Adaptation and Vulnerability in Watershed Areas and Communities in Southeast Asia. Report from AIACC Project No. AS21 (Annex C, 95-126). International START Secretariat, Washington, District of Columbia. Available at: http://sedac. ciesin. org/aiacc/progress/FinalRept_AIACC_A S21.pdf.
Hulme, M. and N. Seard, (1999). Climate Change Scenarios for Indonesia. Climatic Research Unit, Norwich, UK.

"Indonesia is $3^{\text {rd }}$ largest greenhouse gas producer due to deforestation". Available at: http://www. mongabay. com. Accessed on 26 March 2007.

Kanekiyo, K., (2010). Geopolitics of Energy and Global Warming in Northeast Asia, originally published in the Geopolitics of Energy. Available at: http://www.ceri.ca. Accessed on 10 June 2010.

Marceau, M.L. and VanGeem, M.G., (2007b). Solar Reflectance of Concrete for LEED Sustainable Sites Credit: Heat Island Effect, SN2982, Portland Cement Association, Skokie, Illinois, USA.

Mintorogo, D.S., (2008). Horizontal and Vertical Solar Radiation in Surabaya.

Murray I., (2008). Global Warming Economics: Facts vs. Myths, CEI n Point, Competitive Enterprise Institute, Washington

Robinson A. B and Zachary W.R., (1997). Science Has Spoken: Global Warming is a Myth, The Wall Street Journal, Dow Jones \& Co., Inc. 